\title{
Review Of International Law (Lex Specialis) On The Problems Of The South China Sea (SCS) Boundary Conflict And The View Of Indonesia's Diplomacy
}

\author{
Yohanes Firmansyah ${ }^{1}$, Yana Sylvana $^{2}$, Hanna Wijaya ${ }^{3}$, Michelle Angelika $\mathrm{S}^{4}$ \\ ${ }^{1234}$ Health Law Postgraduate Student, Pembangunan Negeri Veteran Jakarta \\ University
}

Corresponding Author: ${ }^{1 *}$ yohanesfirmansyah28@gmail.com, ${ }^{2}$ sylvanayana@gmail. com, ${ }^{3}$ bannwijaya@yahoo.com, ${ }^{4}$ michelleangelika111@gmail.com

Article

History:

Submit:

2020-10-13

Publish:

2021-05-11

\section{Abstract}

The South China Sea (SCS) is a geographical area that is rich in natural resources such as crude oil and is a very strategic area of the economy. The SCS is surrounded by several littoral states which cause conflicts between coastal countries over the right to power over South China. There are at least 9 countries conflicting with each other in the SCS, such as the People's Republic of China (PRC), Taiwan, Malaysia, Vietnam, the Philippines, Brunei Darussalam, Burma and Indonesia. The problem became even more serious when the Declaration of Decision of the International Court of Justice or the Permanent Court of Arbitration (PCA) as the highest international institution was opposed by China because it was considered detrimental and weakening China's power. This research aims to specifically discuss the geographical position of the SCS and international law (especially UNCLOS), diplomacy issues in the maritime sector, how to regulate sea areas according to international law and disputes that occur in the SCS and the role of Indonesian diplomacy in responding to the decision of the Permanent Court of Arbitration (PCA)

Keywords: South China Sea; Conflicts between coast countries; International law; UNCLOS; Permanent Court of Arbitration (PCA) 
Journal Homepage http://ijssr.net/index.php/ijssr

This is an Open Access article under the CC BY SA license

https://creativecommons.org/licenses/by-sa/4.0/

Published by Indonesian Academy of Social and Religious Research

\section{Introduction}

The South China Sea (SCS) is marine waters that are bounded or surrounded by many countries in Southeast Asia. The SCS is known to have enormous and almost unlimited wealth. The wealth in question is the marine or marine potential in the form of fish; reserves of energy sources in the form of oil and gas are estimated to be the second oil reserves in the world after Saudi Arabia. This potential wealth possessed by the SCS is a strategic problem and most triggers conflict in the 21 st century. ${ }^{1}$

Based on history (historical), Beijing claims ownership of 95 percent of the SCS area and makes $85 \%$ of the area became the center of China's crude oil import activities. Furthermore, China also carried out reclamation and declared ownership of small islands in the SCS region and built a military center covering an area of 1,300 hectares. $^{2}$

In more than 100 years, the SCS is a strategic area that supports the history of human life. It is very valuable in terms of the economy of various surrounding countries, such as the Philippines, Brunei, Malaysia, and Vietnam. The problem is not only limited to the area around the SCS but spreads to other countries that do not claim the site but have conflicts of interest over the area. Such as Japan and South Korea, which rely on this region to meet their energy needs, and the United States, which plans to establish a Pacific fleet base in 2021. One of the conflicts that have emerged with Indonesia is the problem of the Natuna Sea, which has huge natural gas reserves. ${ }^{3}$

The economies of Asia, especially Southeast Asia, which intersect with the SCS, have experienced quite rapid economic growth in the past two or two decades. This demands legal certainty for stability and access around the SCS for the sake of the global economy. Various friction and problems arose

1 Dae In Lee, Hyeon Seo Cho, and Sun Beom Jeong, "Distribution Characteristics of Marine Litter on the Sea Bed of the East China Sea and the South Sea of Korea," Estuarine, Coastal and Shelf Science, 2006, https://doi.org/10.1016/j.ecss.2006.06.003.

2 Pete Cobus, "Konflik Dan Diplomasi Di Laut," Voice of America, 2019.

3 Cobus. 
between the Chinese security forces and fishers from other countries around the SCS, which triggered multiple issues and international conflicts. Many of the Western countries (Europe and America have forced and urged Beijing to comply with the rules written in the United Nations Convention on the Law of the Sea (UNCLOS). This regulation regulates maritime control zones based on local coastlines. However, China rejects the statute passed by the United Nations (UN) because it contradicts China's existing national law and the Chinese view that the regulation is a means and tool to undermine China's influence as a power that is very developing. ${ }^{4}$

A panel of five judges in the city of Hague has rejected China's legal basis for claiming ownership of the SCS. After a few weeks, the Supreme Court of China issued fairly strict regulations and committed to prosecuting all foreign parties fishing or fishing in the disputed SCS region. All alternative paths that have been launched to resolve this problem have failed miserably; even the Code of Conduct drawn up by ASEAN will not have a significant impact in resolving issues of conflict and claims of sovereignty over the SCS region. As with other international law (UNCLOS) and the ASEAN, the declaration is predicted not to have a law enforcement mechanism for the SCS issue. ${ }^{5}$

This research discusses the literature review regarding international legal issues, especially UNCLOS, in dealing with conflict problems at sea. UNCLOS is in an important spotlight because of the role of UNCLOS, which acts as a "lex specialis" and originates from the International Court of Justice, which should bind all countries in the coverage area.

\section{Formulation of the problem}

This study raises the fundamental problems of the SCS conflict, namely (1) Geographical Position of the SCS and the Root Problems of Maritime Diplomacy; (2) Position of the SCS in the View of International Law; (3) Arrangement of Sea Territory Boundary According to International Law; (4) The SCS Dispute under international law; (5) The Role of Indonesian Diplomacy in Responding to the Decision of the Permanent Court of Arbitration (PCA)

\footnotetext{
Cobus.

5 Cobus.
} 


\section{Research Methods}

This paper is research that reviews the normative juridical. As for what is meant by normative legal research in the form of research carried out using analysis and synthesis of deductive conclusions from various statements in various secondary data sources such as library materials (literature, books, journals, written documents) or secondary legal material (legislation, legal theories, previous court decisions, doctrine, expert opinion) all of which are relevant and related to the main issues discussed in this journal. The approach used in this research is in the form of 3 methods starting with a statutory procedure, a conceptual process, and an analytical approach. The specifications of this research are prescriptiveanalytical in which all data synthesis, discussion, and data conclusions are analyzed with a broad method in the form of qualitative research. ${ }^{6}$

\section{Results And Discussion}

\section{A. Geographical Position of the South China Sea and the Roots of Problems in Maritime Diplomacy}

The Geographical Position of the SCS and the Roots of Problems in Maritime Diplomacy The SCS is part of the Pacific Ocean that stretches from the Malacca Strait and Singapore in the southwest to the Taiwan Strait in the northeast. The waters of the SCS include the Gulf of Siam, which is bordered by Malaysia, Thailand, Cambodia, Vietnam, and the Gulf of Tonkin, which is bordered by China and Vietnam. The SCS area, when viewed in the international ocean system, is an area of strategic, political, and economic value. This area is very important because of its geographical potential as well as the potential of its natural resources. This area includes more than 200 small islands, corals, and coral reefs, mostly in the Paracels and Spratlys. The SCS is one of the most important and strategic waters in international shipping not only for China and the ten claimants but also for other major countries. For Japan, this sea is a shipping route for oil tankers from the Middle East through the Strait of Malacca as well as a trade route or transportation of raw materials. The US utilizes the SCS as an alternative route for the shipping route that connects the west coast of the US to the Persian Gulf. These waters are also traversed by commercial ships in carrying out trade activities with Southeast Asian and East Asian countries. For Russia, the sea is a shipping route used for oil traffic and commercial ships. ${ }^{7}$

6 Johnny Ibrahim, Teori \& Metodologi Penelitian Hukum Normatif, Teori Metodologi Penelitian A., 2006.

7 Brian Morton and Graham Blackmore, "South China Sea," Marine Pollution Bulletin, 2001, https:// doi.org/10.1016/S0025-326X(01)00240-5. 
As mentioned above, apart from being busy as trade traffic and shipping lanes, the SCS also has several invaluable natural wealth potentials. According to research conducted by The Committee for Coordination of Joint Prospecting for Mineral Resources in Asian Offshore Areas, Economic Commission for Asia and the Far East, since the 1960s, potential minerals have been found, especially oil and gas. According to Chinese estimates, the level of Spratly oil production reaches 1.4-1.9 million barrels per day. Apart from oil and gas content, the SCS also has great potential for variations in fish species. The geographical location of the sea adjacent to several straits allows fish migration from one EEZ to another. Almost half of the SCS is covered by the continental shelf so that it can be used as a commercial base for fishing and sedentary fish. ${ }^{8}$

Coastal countries such as Brunei Darussalam, Malaysia, Philippines, Vietnam, Taiwan, and China have declared their ownership and sovereignty in the territorial areas of the SCS based on several methods such as administrative jurisdiction, occupation, discovery. Confirmation of international treaties (guarantee of ownership by international treaties), international recognition, the peaceful and continuous exercise of authority ( 45 command views), transfer of rights from other countries (rights of succession from foreign governments), historical developments, sovereign rights to the continental shelf, and sovereign rights over the EEZ. From a total of six countries in the coastal area of the SCS, it is known that China is the first country to declare ownership of the SCS area. ${ }^{9}$

The basis for China's declaration of the SCS Region is due to the discovery of historical facts or evidence, maps, ancient documents, site discoveries, and the use or designation of island groups by China. According to historical records, it is known that Chinese anglers have been fishing in the SCS since 2000 years ago and have occupied the Spartly Islands in 206-220 BC based on Chinese archaeological discoveries dating from the Han Dynasty. The SCS is an important asset for China to support economic development and increase China's influence in security, defense, and politics. ${ }^{10}$

Historical discoveries and artifacts have always been the reasons used by China to retain ownership rights to the SCS. China continues to maintain this by engaging in provocation (in the form of a show of force) to all other countries

8 M. Taylor Fravel, "China's Strategy in the South China Sea," CONTEMPORARY SOUTHEAST ASIA, 2011, https://doi.org/10.1355/cs33-3b.

9 Morton and Blackmore, "South China Sea."

10 B. Taylor and D. E. Hayes, "Origin and History of the South China Sea Basin.," The Tectonic and Geologic Evolution of Southeast Asian Seas and Islands. Part 2, 1983, https://doi.org/10.1029/gm027p0023. 
demanding ownership of the SCS. As seen in its policies since the early 1970s until now, China has intensively demonstrated symbols of its sovereignty and is often seen as aggressive by carrying out attacks on foreign ships crossing the waters of the SCS to maintain new potential sources that can support its national interests. ${ }^{11}$

\section{B. Position of the South China Sea in the View of International Law}

Claims to the SCS by states are often based on historical reasons alone. This historical claim causes uncertainty in the ownership of the SCS area. Each country declares the right of the SCS area based only on historical reasons, and this is prone to causing conflicts between nations. The 1982 UNCLOS regulations describe problems between closed or semi-closed seas based on several criteria in which closed and semi-closed sea problems are contained in CHAPTER IX Articles 122-123 UNCLOS 1982. Article 122 defines a closed or semi-closed sea as a bay (basin) or sea which is geographically surrounded by at least two countries (can be more) and connected to other seas or oceans through a narrow lane or entirely or mainly consisting of the territorial sea and the EEZ of two or more coastal States. ${ }^{12}$

Countries bordering closed or semi-closed seas are encouraged to cooperate in carrying out the management of biological resources, establishing policies, and carrying out research and environmental activities. This problem is also explained in Article 123 UNCLOS 1982, in which countries directly adjacent to closed or semi-closed seas should cooperate in exercising their rights and obligations. Therefore states should endeavor through appropriate regional organizations to (1) coordinate all forms of management, exploration, and exploitation of marine biological resources; (2) coordinating the implementation of rights and obligations in the framework of providing protection and preservation of the marine environment; (3) coordinating all forms of ongoing policy and research / scientific activities and collaborating (if necessary) together in an area; (4) to invite, as critical, other countries or international organizations having the interest to cooperate with them in the further implementation of the provisions of this article. ${ }^{13}$

\footnotetext{
11 Taylor and Hayes.

12 Jill Steans and Llyod Pettiford, Hubungan Internasional: Perspektif Dan Tema, 1st ed. (Yogyakarta: Pustaka Belajar, 2009).

13 Steans and Pettiford.
} 
According to international law, the SCS is a semi-closed sea, which means that the SCS is geographically and legally surrounded by various coastal countries such as the People's Republic of China (PRC), Taiwan, Malaysia, Vietnam, Philippines, Brunei Darussalam, and Indonesia. This makes the status and position of the SCS very strategic, but it is rich in conflicts of interest that have sparked conflicts and disputes between all countries around the SCS. ${ }^{14}$

International relations that occur between international legal subjects (individuals, countries, and international organizations) do not always work well. One example of a bad relationship is conflicts or disputes caused by problems of national borders (sovereignty), issues of natural resources (oil and other natural resources), environmental, economic, and trade problems, and many more. To overcome this problem, an instrument is needed to solve or can act as an alternative. One of the means that is intended is international law, which is expected to play its role in solving various types of problems between countries. ${ }^{15}$

Since the 1990s, the SCS region has been the prima donna of security issues in international relations in ASEAN, especially after the Cold War. This area is a sea basin that borders various countries around the coast, such as Taiwan, Burma, Malaysia, the Philippines, Vietnam, and China. In this sea basin there is a Spratly Islands and Paracel Islands. International problems often concern the issues of these two islands. The Spratly Islands are more prominent due to their geographic location, which involves several ASEAN countries at once. ${ }^{16}$

In contrast, the Paracel Islands only sparked conflict between China and Vietnam. The dispute in the SCS dates back to the late 19th century when Britain, China (early 20th century), and France (1930) claimed the Spratly Islands. During World War II, Japan had used the Spratly Islands as the center of a submarine base after driving out French occupation and. After the Second World War, China and France reclaimed the territory and was followed by the Philippines, which needed part of the site as part of its national security interests. ${ }^{17}$

The opening of opportunities to exploit the SCS region automatically encourages countries whose coasts are directly adjacent to the area to immediately claim some islands, islands, or reefs that are included in the territory of their country as determined by international maritime law. Vietnam, Malaysia, the

14 Bambang Cipto, Hubungan Internasional Di Asia Tenggara (Teropong Dinamika, Realitas Dan Masa Depan), 1st ed. (Yogyakarta: Pustaka Belajar, 2007).

15 Cipto.

16 Cipto.

17 Cipto. 
Philippines, and China are competing to claim, sending troops to secure the islands they claim. Claims made by these coastal states that are directly adjacent to the SCS often violate provisions of international maritime law, causing disputes and leading to conflicts between these countries. Dispute or conflict in the SCS continues to develop until now. To which the end of 2014 until now, there has been a dispute or conflict. The disagreement or conflict that occurs is related to the reclamation carried out by the PRC on disputed islands in the SCS. ${ }^{18}$

\section{Regulation of Maritime Territory Boundaries According to International Law}

Territorial sea area regulation in terms of international law is regulated based on the drawing of a territorial sea baseline, which in its application is handled by two methods of rules, namely the nine-dash line method carried out by China and the method of determining boundaries based on the territorial sea basement line, the continental shelf and Exclusive Economic Zone (EEZ)—regulated in the 1982 UNCLOS law of the sea convention. ${ }^{19}$

The nine-dash line method has extended from the territorial sea of China to the high seas, the EEZ, and the continental shelf claimed by countries around the SCS. The Chinese application of the nine-dash line method was followed by efforts to enforce the law in the SCS region unilaterally. However, the application of the straight base nine-dash line method is not known in the doctrine of the law of the sea or the regulation of the UNCLOS Convention on the Law of the Sea in 1982. Therefore, the PCA Decision states that the use of the nine-dash line method from China is unacceptable because it contradicts the International Law of the Sea Convention and is clear. As a violation of international law. ${ }^{20}$

The nine-dash line method is not without foundation, but the manner claimed by the Chinese is recognized as a historical basis (historical). The Chinese historical basis is that maps of the SCS islands have been published throughout the Ming and Qing dynasties, including navigation maps compiled in the 13th century by Admiral Cheng Ho. China's claim is based on the understanding that the territorial features of the SCS are territories historically held by China of sovereign jurisdiction, that is, "ancestral property" passed down from previous

18 Steans and Pettiford, Hubungan Internasional: Perspektif Dan Tema.

19 Institut for Security \& Development Policy, "Understanding China's Position on the South China's Disputes, June 2016," Stockholm, 2016.

20 Institut for Security \& Development Policy. 
generations. The reasons for China claiming the SCS area are due to various reasons, for example: (1) China's activities in the SCS occurred more than 2000 years ago"; (2) China became the first country to discover, name, explore and exploit the resources of the islands of the SCS and the first to continue to exercise sovereign power over the region. (3) Chinese ownership of the SCS islands was recognized by France, Germany, Britain, and the Soviet regional atlas published in the 1950-1960s. (4). The Chinese government rejects territorial claims by other SCS claimants (especially the Philippines). The territorial claim should not include marine features within the dotted line area until the 1970s.; (5) From Beijing's perspective, it shows that claims from other countries are relatively new, politically motivated, and further driven by resource extraction. ${ }^{21}$

The waters of the SCS covering an area of approximately 3,500,000 square kilometers, including the surrounding islands, are claimed to be owned by ten countries, namely China, Cambodia, Singapore, Indonesia, Malaysia, Thailand, Vietnam, Philippines, and Taiwan. China itself claims the waters of the SCS based on 9 (nine) dashed lines stretched in the SCS region, which includes the EEZ of Vietnam, Taiwan, Singapore, Philippines, Malaysia, Indonesia, and Brunei. Vietnam makes claims around the maritime boundary along the Vietnam coast and the Paracel Islands. Taiwan claims several territories in the Spratly Islands and Burnt Scarborough (which is also disputed by the Philippines and China). The Spratly Islands themselves are disputed between China and 5 (five) countries, namely Brunei Darussalam, Malaysia, Philippines, Vietnam, and Taiwan. Problems occurred in 1996 when Japan built a lighthouse on the island of Spratly, but Taiwan and China also jointly claimed ownership of the island. Likewise, Malaysia and the Philippines each demand overlapping parts of the Spratly group of islands. ${ }^{22}$

The nine-dash line method claimed by China is new as state practice and has been tested through the Permanent Court of Arbitration. Although in the end, the 2016 Permanent Court of Arbitration decision could not be accepted and rejected by the Chinese side. Whereas the Permanent Court of Arbitration is a judicial institution established by the international community, and its decisions must be followed by all countries that are the scope of the Permanent Court of Arbitration. China's refusal is a challenge for the international community in resolving conflicts in marine areas, especially the $\mathrm{SCS}^{23}$

${ }^{21}$ Institut for Security \& Development Policy.

22 Institut for Security \& Development Policy.

23 Mauna Boer, Hukum Internasional, Pengertian Peranan Dan Fungsi Dalam Era Dinamika Global, 2nd 
The Convention on the Law of the Sea by the UN was declared adopted on April 30, 1982, and signed on December 10, 1982, in Montego Bay, Jamaica, then was declared to enter into force internationally since November 16, 1994. Thus, for the first time, there are provisions of international law regarding the width of the sea area. Indonesia has ratified the Law of the Sea with the Law of the Republic of Indonesia Number 17 of 1985 concerning the Ratification of the International Convention on the Law of the Sea from the UN. This provision is very important to reduce one of the possible sources of disputes between countries to one another in the field of maritime law. Receiving a sea width of 12 miles is not so difficult because it has been a general trend since the previous few years. ${ }^{24}$

The 1982 UNCLOS International Law of the Sea Convention, Chapter II on Territorial Seas, and Additional Zones discusses several provisions regarding the method or method of drawing baselines by coastal or coastal States. Article 3 discusses the right of the coastal State to determine the width of its territorial sea to a length that does not exceed 12 nautical miles, measured from baselines determined by the provisions of this Convention. Article 4 describes the outer boundary of the territorial sea, which is a line where the distance of each point from the point closest to the baseline is equal to the width of the territorial sea in the coastal State. Article 5 deals with the rules and provisions of the normal baseline (unless otherwise provided in this Convention). Article 5 discusses that below the usual baseline for measuring the width of the territorial sea is the low water line along the coast, as shown on the outline of the scale map, which is officially recognized by the State coast (classical method). Infield application, it is known that this method is very difficult to implement, especially for countries that have crooked beaches and which have many islands close to the coast. This provision is further discussed in Article 7, Clause 1 of the 1982 Convention. Besides, this straight-line drawing is not carried out carelessly, but some conditions govern and are spelled out in Clauses 2, 3, 4, 5, and 6. Article 7, Clause 1 explains that in places where the coastline induces inward and rotates inward or if there is a series of islands along the coast nearby (geographically metering), the method of drawing a straight baseline connecting the correct points can be used in drawing baselines from which the width of the territorial sea is measured. Clause 2 further explains that where due to deltas and other natural conditions, the coastline is very unstable (geographical mapping), suitable points can be selected

ed. (Bandung: Penerbit Alumni, 2008).

24 Boer. 
on the route (as long as it is relevant) even for the low water areas that extend the furthest. To the sea, and even if the short waterline subsequently retreated, the straight baseline shall remain in effect until amended by the coastal State under this Convention. Clause 3 states that the baselines referred to in Clause 2 should not deviate too far from the general direction of the coast and that the part of the sea that falls within the baseline must be close enough to land to be subject to the inland water regime. Further, Clause 4 states the prohibition that straight baselines should not be drawn to and from the low tide unless lighthouses or similar installations are permanently erected above sea level or unless baselines to and from this height have received general international recognition. Clause 5 (refers to clause 1) discusses the matter of determining certain baselines to take into account the special economic interests of the region concerned, whose reality and importance are proven in a long-term study. Clause 6 states that a State cannot or is prohibited from drawing a straight baseline in such a way as to intersect the territorial sea of another State from the high seas or EEZ. The Convention also affirms that the detailed baseline drawings shall not deviate too far from the reasonable limits or the general direction of the coast and that the parts of the sea within must be closely related to the baseline and linked to the coastline or islands in the sovereignty of the area. In brief, all of these provisions discuss two important points that (1) a straight baseline should not be drawn to and from low tide, unless a lighthouse or similar installation is permanently installed above sea level or unless a baseline drawing to and from this height has received general international recognition; (2) A country may not apply a linear baseline drawing system in such a way as to cut off another country's territorial sea from the high seas or EEZ. ${ }^{25}$

Issues regarding the legal status of the sea, which lies on the inside as a result of taking a straight baseline, are discussed and further emphasized in the 1982 Convention on the Law of the Sea, Article 8 Clause 1. This section discusses inland waters (unless stipulated in Chapter IV) are waters in the land side of the baseline of the territorial sea is part of the internal waters of a State. Clause 2 provides that if the determination of a straight baseline according to the method specified in Article 7 results in the closure of inland waters from areas not previously considered to be such, then in those waters, the right of innocent passage as defined in this Convention will apply. The uniqueness of this

25 UNCLOS, "Convention on the Law of the Sea 1982," in The Law of the Sea: Progress and Prospects, 1982, https://doi.org/10.1093/acprof:oso/9780199299614.003.0002. 
provision is that it is something new in the law of the sea that discusses the right of peaceful passage in inland sea areas, such as in the territorial sea. The method of establishing baselines by the coastal State has been affirmed in Article 14 of the Convention, which provides that the coastal State can alternately establish baselines using one of the delineation methods set out in the above article to suit different circumstances. Article 15 further discusses that if there are beaches/ coasts that are located opposite or bordering each other (between 2 countries), then none of them have the right, unless there is a conflicting agreement between them, to determine the boundaries of their territorial sea, which exceeds the diameter of a point equidistant from the nearest point on the baseline from which the width of the territorial sea of each State is measured. However, the above provisions do not apply if the basis of the claim is only based on historical or other special circumstances. ${ }^{26}$

About the baseline for measuring the width of the territorial sea shall be included in the Map and list of geographic coordinates of the coastal State, as determined by Article 16 of the UNCLOS 1982 Law of the Sea Convention, as follows: (1) The baseline for measuring the width of the territorial sea as stipulated in article 7,9 and 10, or the boundary line resulting from these provisions and the boundary line drawn under articles 12 and 15, shall be shown on the Map of a scale or scales sufficient for the determination of the position line. Instead, a list of geographic coordinate points may be provided, describing the geodetic datum; (2) The coastal State shall make an appropriate announcement of the Map or list of geographic coordinates and deposit one copy/derivative of each Map or list with the Secretary-General of the UN. ${ }^{27}$

As with the method of taking baselines in the territorial sea from which the width of the 12-mile territorial sea is measured, the baseline process is different in determining baselines on the continental shelf and EEZ, which is 200 miles wide. Article 57 states that the width of the EEZ must not exceed 200 nautical miles from the baseline from which the width of the territorial sea is measured. Article 55 further explains that the EEZ is an area outside and bordering the territorial sea which is subject to a special legal regime regulated in this Chapter based on where the rights, jurisdiction of the coastal State, and the relevant provisions of this Convention control the rights and freedoms of other States. According to Article 56, the rights, jurisdiction, and obligations of the coastal

26 UNCLOS.

27 UNCLOS. 
State in the EEZ include (1) Sovereign rights for exploration, management, conservation, and exploitation of natural resources for economic purposes; (2) The jurisdiction governed by the relevant provisions of this Convention for a) the manufacture and use of artificial islands, installations, and structures; b) marine scientific research; c) protection and preservation of the marine environment; (3) Other rights and obligations as defined in this Convention. (4) In exercising their rights and fulfilling their obligations under this Convention in the EEZ, the coastal State must pay attention to the rights and obligations of other States. It shall act in a manner consistent with the provisions of this Convention. (5) Chapter VI must exercise the rights mentioned in this article regarding the seabed and the land under it. ${ }^{28}$

The methods that can be used to resolve conflicts regarding the granting of rights and jurisdiction in the EEZ are regulated by Article 6, which states that this Convention does not give rights or jurisdiction to coastal States or other States in the EEZ. If a dispute arises between these countries, the conflict must be resolved based on the principle of fairness without overriding various relevant considerations to provide the best decision for all parties involved. ${ }^{29}$

Determination of baselines for the width of the continental shelf or boundaries of the continental shelf has been regulated by Article 76, which discusses at least ten main points, namely, (1) The continental shelf of a coastal State starts from the seabed and the land below it from the area below sea level located in the beyond its territorial line along with the natural continuation (by geography) of its land area to reaching the outer edge of the continent, or up to 200 nautical miles from the baseline from which the width of the territorial sea is measured if the outer edge of the continent does not reach a distance. (2) The continental shelf of a coastal State may not exceed the limits defined in Clauses 4 to 6; (3) The edge of a continent includes the continuation of the part of the coastal State which is below the water surface, and all of it consists of the seabed and the land beneath it from the continental plain, slope, and rise. This continental shelf does not cover the deep seafloor with evidence of the oceans or the ground below; In the fourth point (4a), it is explained that the method of determining a continental shelf wider than 200 nautical miles is measured using "a line drawn by Clause 7 regarding the outermost fixed point where the thickness of the sediment is at least $1 \%$ of the closest distance between it and

28 UNCLOS.

29 UNCLOS. 
the foot of the continental slope"; or it could be "a line drawn at fixed points not more than 60 nautical miles from the foot of the continental slope." (4b) If there is no evidence to the contrary, the foot of the continental slope shall be determined as the point of change for the maximum slope in feet. (5) It is further explained that the line measured in the fourth statement ( $4 \mathrm{a}$ and $4 \mathrm{~b})$ must not exceed 350 nautical miles from the baseline where the territorial sea is located and shall not exceed 100 nautical miles from the depth line of 2,500 meters (isobath), that is, the line connecting depth of 2,500 meters; (6) The clauses governed by clause 5 do not apply to the sea floor level which is a natural part of the continental shelf, such as plateaus, inclines, covers, banks and spurs; (7) The coastal State shall determine the outer limit of its continental shelf where the continental shelf exceeds 200 nautical miles from the baseline from which the territorial sea is measured by drawing a straight line not exceeding 60 nautical miles, connecting fixed points, which are determined by latitude and longitude; (8) Information regarding the boundaries of the continental shelf beyond 200 nautical miles from the baseline from which the territorial sea is measured to the Commission on Continental Shelf Boundaries determined in accordance with Annex II on the basis of fair geographic representation. This Commission will make recommendations to the coastal States on matters relating to their continental shelf boundaries. The continental shelf boundaries established by the coastal State based on this recommendation are final and binding; (9) The coastal State shall keep with the Secretary-General the relevant maps and information including geodetic data, which permanently delineates the outer boundaries of its continental shelf and the Secretary-General must publish these maps and information by applicable regulations; (10) The provisions of this article shall not prejudice the problem of delimitation of the continental shelf between States which are geographically opposite or adjacent to each other. ${ }^{30}$

Further discussion regarding the determination of the continental shelf between countries with opposite or bordering beaches is regulated by Article 83 which explains several things, namely: (1) The resolution of the boundaries of the continental shelf between States whose coasts are opposite or bordering must be carried out by agreement based on international law (Article 38 of the Statute The International Court of Justice) to reach a fair settlement; (2) If no agreement can be reached within a reasonable time, the State concerned shall use the procedure specified in Part XV; (3) While awaiting the agreement provided for in this

30 UNCLOS. 
Clause 1, the States involved will make every effort to make practical interim arrangements and, during this transitional period, do not endanger or interfere with the achievement of the agreement (based on the principle of understanding and cooperation); (4) In the case of an agreement in force between the States concerned, matters relating to the boundaries of the continental shelf must be determined on the basis of the provisions of the agreement. ${ }^{31}$

\section{The South China Sea dispute is reviewed from international law}

Since late 2014 until now, the PRC has been actively carrying out the reclamation of several islands in the SCS. The issue of reclamation carried out by the PRC has also become an issue that is currently being discussed in the SCS region. This is because many countries are involved in this reclamation issue so that the issue of reclamation carried out by the PRC on disputed islands in the SCS has attracted the attention of the international public. ${ }^{32}$

Reclamation (land reclamation) is the process of making new land from the seabed or river bed. Land that is reclaimed is called reclaimed land or landfill. Reclamation can be defined as a work or effort in the use of an area of land that is useless and watery to become usable land by drying it. Places that are usually used as a place for reclamation such as coastal, offshore or offshore areas, lakes, swamps or rivers that are so wide

The reclamation carried out by the PRC is indeed aimed at making an artificial island. This reclamation was carried out on several islands in the Spratly Islands. The Spratly Islands are one of the largest islands in the SCS region and are also one of the islands where disputes occur. The islands of the Spratly Islands which are the site of the reclamation include Mischief Reef, Fiery Cross Reef and Subi Reef. The place (islands) are coral islands that cannot be occupied by humans. However, the PRC later transformed the islands into habitable artificial islands. ${ }^{33}$

The artificial islands reclaimed by the PRC were later built on top of an airstrip and other facilities. The PRC government claims to have the right and ability to restore islands and reefs that are illegally occupied by neighbouring countries. The runway over the artificial island was discovered after satellite imagery revealed that the PRC had built an airstrip on an artificial island in

\footnotetext{
31 UNCLOS.

32 Cipto, Hubungan Internasional Di Asia Tenggara (Teropong Dinamika, Realitas Dan Masa Depan).

33 Lee W. Saperstein, Reclamation, Surface Mining, 1990, https://doi.org/10.1163/18756735-09701009.
} 
the waters of the SCS. The satellite that showed the runway project of the PRC was a satellite from the Center for Strategic and International Studies (CSIS) DigitalGlobe, which is based in Washington, United States (US). The satellite imagery shows that the runway built by the PRC in the SCS is predicted to be 3,110 meters long. ${ }^{34}$

Apart from the airstrip, the PRC has also created a lighthouse on the artificial island. The Government of the PRC emphasized that development in the region is intended to assist activities such as rescue and maritime search, environmental protection, disaster relief, and navigation security, as well as military objectives. Land reclamation carried out by the PRC sparked opposition from many countries. The opposing countries are not only those directly bordering the SCS but also other countries such as the United States (US). The United States strongly opposes the reclamation carried out by the PRC in the SCS, because it is considered to affect freedom of shipping and aviation in the SCS region. Because of this, the US dispatched spy planes to monitor developments in the SCS. The PRC in claiming the SCS area always bases its claim on historical reasons. Historical reasons have always been the basis of the PRC claim in the SCS because that alone can be used as an excuse for the PRC to claim the SCS. The current reclamation of the PRC on disputed islands in the SCS is based on historical reasons. According to the PRC, the SCS region has been controlled by the Han Dynasty for a long time, and historical objects have also been found in islands in the SCS region that are made in China. ${ }^{35}$

It is for these historical reasons that the PRC claimed the SCS and later reclaimed it. The PRC government affirms that the PRC government has the right to carry out reclamation of several islands in the SCS region. The PRC government stated that the reclamation was carried out on the islands belonging to the PRC and did not target other countries. Besides, the government of the PRC said that the development carried out on the artificial island was fair, reasonable and legitimate, also did not affect and target other countries and did not affect freedom of flight and navigation in the SCS region. ${ }^{36}$

To find out whether or not the reclamation carried out by the PRC on disputed islands in the SCS region must be studied according to the applicable

34 Murray Hiebert and Gregory Poling, "The South China Sea," in In Pursuit of Prosperity: U.S. Foreign Policy in an Era of Natural Resource Scarcity, 2014, https://doi.org/10.4324/9781315858029-11.

35 Hiebert and Poling.

36 Robert D. Kaplan, "The South China Sea Is the Future of Conflict," Foreign Policy, 2011, https://doi. org/10.2307/41353198. 
international maritime law. The global marine law in question is the UN Convention on the Law of the Sea in 1982 or better known as UNCLOS 1982. Apart from the 1982 UNCLOS, this reclamation issue also needs to be linked to the provisions contained in the Declaration On The Conduct Of Parties In The SCS (DOC) in 2002. This is because DOC 2002 is a code of conduct for ASEAN countries and the PRC in the SCS region. ${ }^{37}$

The reclamation carried out by the PRC on disputed islands in the SCS violates the 1982 UNCLOS provisions governing semi-closed sea provisions. The reclamation carried out by the PRC is a one-sided reclamation not as a form of cooperation, coupled with the statement of the PRC claiming the right to reclamation on disputed islands in the SCS region shows that the People's Republic's stance is against the 1982 UNCLOS. $^{38}$

UNCLOS 1982 explains that a country can only claim 200 miles of sea area. More than 200 country miles are no longer eligible. The reclamation carried out by the PRC is illegal because the reclamation area carried out by the PRC has exceeded the 200-mile limit and is not included in the territory of the PRC EEZ. Reclamation carried out by the PRC is possible if the reclamation is carried out in the EEZ of the PRC. As explained in UNCLOS 1982, the coastal State has the exclusive right to build and regulate the construction of artificial islands. ${ }^{39}$

In UNCLOS 1982 Article 21, it is explained that the maritime zone can extend its territory not only from the mainland of the coastal State but also from every island that is in its sovereign territory. This article also defines an island as a land that is formed naturally, and the land is surrounded by water and the land remains above water even at high tide. However, "rocks that cannot support human habitation or economic life in isolation" are only entitled to 12 nautical miles of territorial territory, not the EEZ or the continental shelf. The elevations are submerged at high tide, and artificial islands have no rights in adjacent waters. From this explanation, it can be seen that coral islands in the SCS area cannot be used as a basis for China to claim the SCS area. And the artificial islands that PRC has built on its reclaimed mainland of disputed islands in the China Sea Ocean Sea cannot serve as a basis for the PRC to claim its SCS territory. This is because the artificial islands built by the PRC are not in the PRC's EEZ, but overlap with other countries' EEZs. In addition, according to UNCLOS 1982,

37 UNCLOS, "Convention on the Law of the Sea 1982."

38 UNCLOS.

39 UNCLOS. 
artificial islands do not have the status of islands, and their existence will not affect the determination of territorial sea boundaries, EEZ, or the continental shelf of the countries that build the artificial islands. ${ }^{40}$

The construction of an artificial island may raise legal questions if it occurs within another country's EEZ. On the other hand, reclamation carried out on the high seas was allowed under UNCLOS 1982. As a result, reclamation activities of the PRC were allowed depending on the zonal boundaries between surrounding countries. The PRC claims sovereignty over Taiwan without controlling it, and Taiwan occupies Itu Aba, which is the largest island in the Spratly Archipelago and is widely recognized to be a natural island according to the 1982 UNCLOS definition. Therefore, the PRC may seek to claim reclaimed territory. Through Itu Aba. However, these claims will overlap with the EEZ of the Philippines on Palawan Island.

In addition to violating the 1982 UNCLOS, the reclamation carried out by the PRC on disputed islands in the SCS also violates the provisions of the 2002 DOC which were mutually agreed upon between ASEAN member countries and the PRC. In the 2002 DOC, it was explained that the parties, namely the ASEAN member countries and the PRC, tried to refrain from carrying out activities that would complicate or increase disputes and affect peace and stability in the SCS region. Meanwhile, the reclamation carried out by the PRC violates the spirit of cooperation contained in the 2002 DOC, because the reclamation carried out by the PRC causes disputes and disrupts peace and stability in the $\mathrm{SCS}$ region. From the above explanation, it can be concluded that the reclamation action carried out by the PRC on disputed islands in the SCS is contrary to international maritime law, namely UNCLOS 1982 and DOC 2002. ${ }^{41}$

\section{E. The Role of Indonesian Diplomacy in Responding to the Decision of the Permanent Court of Arbitration (PCA)}

The role of Indonesian diplomacy in settlement of disputes in the SCS area is considered very important in line with the Preamble to the 1945 Constitution of the Unitary State of the Republic of Indonesia, the First and Fourth Clauses and Article 11, Article 13 of the 1945 Constitution of the Unitary State of the Republic of Indonesia ${ }^{42}$ and the Law of the Republic of Indonesia Number 24 of

${ }^{40}$ UNCLOS.

${ }^{41}$ UNCLOS.

42 Kemenristekdikti, “Undang-Undang Dasar Republik Indonesia 1945," Resntra Kemenristekdikti 20152019, 2015. 
2000 concerning International Treaties ${ }^{43}$ and Law of the Republic of Indonesia Number 37 of 1999 concerning Foreign Relations. On the other hand, the role of border diplomacy must be carried out by Indonesia as a strengthening, especially for the existence of waters around the waters of the Natuna Islands. ${ }^{44}$ Border diplomacy is in the form of negotiations or negotiations with the right strategy; this strategy is to focus more on strengthening efforts inward by building real border areas so that effective control or effective occupation occurs in border areas.

Law enforcement efforts must follow internal strengthening by carrying out development. It is believed that the Law of the Republic of Indonesia Number 17 of 1985 contains the principles of legal certainty, benefit and justice. If the drawing of a straight baseline for islands connecting the outer points of islands and dry reefs outside the archipelago in Indonesia refers to article 47 of the 1982 UNCLOS, then juridically, the total number of islands in Indonesia will be 17,508 islands, including Natuna and its surroundings. Border diplomacy is also an implementation of state sovereignty which is manifested through the idea of a national world maritime axis, which is a factor in Indonesia's geostrategy. ${ }^{45}$

At the time of signing, ratifying, or accessing this Convention or at any time after that, a State is free to choose, through a written declaration, one or more of the following means for resolving disputes concerning the interpretation or application of this Convention: (1). The International Court of Law of the Sea was established by Annex VI; (2). The International Court of Justice; (3). A special arbitral tribunal established under Annex VIII; (4). A special arbitral tribunal appointed by Annex VIII for one or more types of disputes listed therein.

\section{CONCLUSION}

The SCS is a region rich in natural resources such as crude oil. From a geographic and economic perspective, it is known that the SCS is the center of a very important economic route in ASEAN.The SCS is surrounded by nine coastal

${ }^{43}$ Republik Indonesia, "UNDANG-UNDANG REPUBLIK INDONESIA NOMOR 24 TAHUN 2000 TENTANG PERJANJIAN INTERNASIONAL,” Republik Indonesia § (2000).

${ }^{44}$ Republik Indonesia, "UNDANG-UNDANG REPUBLIK INDONESIA NOMOR 37 TAHUN 1999 TENTANG HUBUNGAN LUAR NEGERI,” Republik Indonesia § (1999).

45 Republik Indonesia, "UNDANG-UNDANG REPUBLIK INDONESIA NOMOR 17 TAHUN 1985 TENTANG PENGESAHAN UNITED NATIONS CONVENTION ON THE LAW OF THE SEA (KONVENSI PERSERIKATAN BANGSA-BANGSA TENTANG HUKUM LAUT,” Republik Indonesia § (1985). 
states that are competing for power over the SCS region. One of the countries that most insist on power in the SCS is China based on historical claims. One way out to settle claims to the SCS is through the International Court of Justice. Still, the decision of the International Court of Justice was opposed by China because it was considered to weaken China's military, economic, and political power in the international world.

The 1982 UNCLOS International Law of the Sea Convention, Chapter II on Territorial Seas, and Additional Zones contains several provisions on the methods of drawing baselines by coastal States. Article 3 provides for the right of the coastal State to determine the width of the territorial sea to a limit not exceeding 12 nautical miles, measured from baselines determined by this Convention. This is by drawing a baseline on the EEZ and a 200-mile wide continental shelf, according to Article 57. On the other hand, the legal arrangement is accompanied by unilateral expansion by China related to the drawing of the territorial sea baselines of the nine-dash line method that extends to the EEZ area and the continental shelf around the LCS because historical reasons are unknown and contrary to the 1982 UNCLOS International Law of the Sea Convention. China's actions have harmed the archipelagic countries around the SCS, including Indonesia, especially the Natuna island region, which was affected by the conflict over the SCS area.

The role of Indonesian diplomacy after the PCA Decision in the Dispute of the SCS Area between China and the Philippines was carried out based on the Preamble of the 1945 Constitution (UUD), First and Fourth Paragraphs, and Article 11, Article 13 of the 1945 Constitution, and Law No.24 of 2000 on Treaties International Law No.37 of 1999 on Foreign Relations. On the other hand, the role of border diplomacy must be carried out by Indonesia as a strengthening, especially for the existence of waters around the waters of the Natuna Islands. Border diplomacy is in the form of negotiations or negotiations with the right strategy. This strategy is to focus more on strengthening efforts inwardly by building real border areas so that effective control or effective occupation occurs in border areas.

\section{Conflict of Interest}

The authors declared that they have no conflicts of interest. 


\section{Acknowledgments}

A big thank you to Diani Sadiawati, SH, LLM, PhD from the Department of International Law Pembangunan Nasional Veteran Jakarta University for guiding us in international law courses.

\section{Author Contribution}

Yohanes Firmansyah and Yana Sylvana played a role in sparking research ideas, making the manuscript, and translating the language. Hanna Wijaya was in charge of finding journal compilation material. Michelle Angelika S contributed to arranging the writing format and revising the manuscript.

\section{Funding}

Self Funding

\section{Reference}

Boer, Mauna. Hukum Internasional, Pengertian Peranan Dan Fungsi Dalam Era Dinamika Global. 2nd ed. Bandung: Penerbit Alumni, 2008.

Cipto, Bambang. Hubungan Internasional Di Asia Tenggara (Teropong Dinamika, Realitas Dan Masa Depan). 1st ed. Yogyakarta: Pustaka Belajar, 2007.

Cobus, Pete. "Konflik Dan Diplomasi Di Laut.” Voice of America, 2019.

Fravel, M.Taylor. "China's Strategy in the South China Sea." CONTEMPORARY SOUTHEAST ASLA, 2011. https://doi.org/10.1355/cs33-3b.

Hiebert, Murray, and Gregory Poling. "The South China Sea." In In Pursuit of Prosperity: U.S. Foreign Policy in an Era of Natural Resource Scarcity, 2014. https://doi.org/10.4324/9781315858029-11.

Ibrahim, Johnny. Teori \& Metodologi Penelitian Hukum Normatif. Teori Metodologi Penelitian A., 2006.

Institut for Security \& Development Policy. "Understanding China's Position on the South China's Disputes, June 2016.” Stockholm, 2016.

Kaplan, Robert D. "The South China Sea Is the Future of Conflict." Foreign Policy, 2011. https://doi.org/10.2307/41353198.

Kemenristekdikti. “Undang-Undang Dasar Republik Indonesia 1945.” Resntra Kemenristekdikti 2015-2019, 2015. 
Lee, Dae In, Hyeon Seo Cho, and Sun Beom Jeong. "Distribution Characteristics of Marine Litter on the Sea Bed of the East China Sea and the South Sea of Korea." Estuarine, Coastal and Shelf Science, 2006. https://doi. org/10.1016/j.ecss.2006.06.003.

Morton, Brian, and Graham Blackmore. "South China Sea." Marine Pollution Bulletin, 2001. https://doi.org/10.1016/S0025-326X(01)00240-5.

Republik Indonesia. UNDANG-UNDANG REPUBLIK INDONESIA NOMOR 17 TAHUN 1985 TENTANG PENGESAHAN UNITED NATIONS CONVENTION ON THE LAW OF THE SEA (KONVENSI PERSERIKATAN BANGSA-BANGSA TENTANG HUKUM LAUT, Republik Indonesia § (1985).

—. UNDANG-UNDANG REPUBLIK INDONESIA NOMOR 24 TAHUN 2000 TENTANG PERJANJIAN INTERNASIONAL, Republik Indonesia § (2000).

—. UNDANG-UNDANG REPUBLIK INDONESIA NOMOR 37 TAHUN 1999 TENTANG HUBUNGAN LUAR NEGERI, Republik Indonesia § (1999).

Saperstein, Lee W. Reclamation. Surface Mining, 1990. https://doi. org/10.1163/18756735-09701009.

Steans, Jill, and Llyod Pettiford. Hubungan Internasional: PerspektifDan Tema.1st ed. Yogyakarta: Pustaka Belajar, 2009.

Taylor, B., and D. E. Hayes. "Origin and History of the South China Sea Basin.” The Tectonic and Geologic Evolution of Southeast Asian Seas and Islands. Part 2, 1983. https://doi.org/10.1029/gm027p0023.

UNCLOS. "Convention on the Law of the Sea 1982." In The Law of the Sea: Progress and Prospects, 1982. https://doi.org/10.1093/acprof:o so/9780199299614.003.0002. 